Business of the Heart 



\section{Business of the Heart}

Religion and Emotion

in the Nineteenth Century

JOHN CORRIGAN

University of California Press

BERKELEY LOS ANGELES LONDON 
University of California Press

Berkeley and Los Angeles, California

University of California Press, Ltd.

London, England

(C) 2002 by the Regents of the University of California

A portion of this book appeared in a somewhat different form in Emotion and Religion: A Critical Assessment and Annotated Bibliography, by John Corrigan, Eric Crump, and John Kloos, published by Greenwood, an imprint of Greenwood Publishing Group, Inc., Westport, Connecticut.

Library of Congress Cataloging-in-Publication Data

Corrigan, John, 1952-

Business of the heart : religion and emotion in the nineteenth century / John Corrigan.

p. $\quad \mathrm{cm}$.

Includes bibliographical references and index.

ISBN 0-520-22196-6 (alk. paper)

1. Revivals-Massachusetts-Boston-History-19th century.

2. Emotions-Religious aspects-Christianity-History of doctrines - 19th century. 3. Protestants-Massachusetts-BostonHistory-19th century. 4. Businessmen-Religious lifeMassachusetts-Boston. I. Title.

Bv 3775.87 C65 2002

$277.44^{\prime} 61081$-dc2x

2001004447

Manufactured in the United States of America

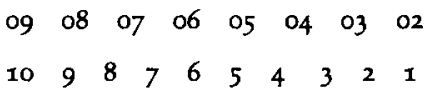

The paper used in this publication meets the minimum requirements of ANSI / NISO Z39 0.48-1992(R 1997) (Permanence of Paper).() 
For Sheila 

The individual ... appears to construct his own life by a calculated, self-conscious, comprehensive activity; by which he obtains an appearance of consistency, and a consciousness of reality, freedom, and accountability. In this process he appropriates for personal use, from the materials furnished by the manifestations of the mind, such forms as correspond with the present wants of his personal constitution; and makes use of the appropriations, in the relation of cause and effect, as means for the production of ends in securing the greatest amount of good that is possible for him, or what is good for him upon the whole. Thus, instead of a dual and discordant consciousness spontaneously realized, the nature of which is incomprehensible to him, he seems to construct for himself a self-conscious, calculated, comprehensible individuality, which is consistent in character, and the composition and operations of which are thoroughly comprehended, because calculated and constructed by himself. We say that the individual appears in this way to construct his own life-that this must so appear to him, in order that any apparent reality or freedom should be communicated to it, - and that it is absolutely necessary that he should believe in his reality, freedom, and accountability; but we do not mean to say that this is the fact.

Ephraim Langdon Frothingham, Philosophy as Absolute Science (Boston, 1864), 225-26

A commodity appears at first sight, a very trivial thing, and easily understood. Its analysis shows that it is, in reality, a very queer thing, abounding in metaphysical subtleties and theological niceties. 
